\title{
Did you wash your caving suit? Cavers' role in the potential spread of Pseudogymnoascus destructans, the causative agent of White-Nose Disease
}

\author{
Violeta Zhelyazkova (D) ${ }^{1}$, Antoniya Hubancheva (D) ${ }^{2}$, Georgi Radoslavov (D) ${ }^{2}$, \\ Nia Toshkova (D) ${ }^{1}$, and Sebastien J. Puechmaille (D) ${ }^{3^{*}}$ \\ ${ }^{1}$ National Museum of Natural History, Bulgarian Academy of Sciences, 1 Tsar Osvoboditel Str., 1000 Sofia, Bulgaria \\ ${ }^{2}$ Institute of Biodiversity and Ecosystem Research, Bulgarian Academy of Sciences, 25 Academic Georgi Bonchev Str, 1113 Sofia, Bulgaria \\ ${ }^{3}$ ISEM, University of Montpellier, CNRS, EPHE, IRD, Montpellier, France
}

\begin{abstract}
White-Nose Disease (WND) has killed millions of hibernating bats in the US and Canada. Its causative agent, the fungus Pseudogymnoascus destructans was introduced to North America, but is native to Europe and Asia, where it is not associated with mass mortality. Although it is nearly impossible to eradicate an emerging wildlife disease, research on $P$. destructans spread mechanisms can aid in prevention of new introductions and development of better environmental management strategies. It is of particular importance to quantify the potential role of people visiting caves (cavers, tourists, bat researchers, etc.) whom inadvertently move $P$. destructans spores between sites, and to limit spread, particularly to areas where the fungus is absent. In the course of two consecutive field seasons, samples were collected from the equipment before and after work in Bulgarian caves where $P$. destructans is present. Viable $P$. destructans spores were isolated from field equipment after nearly $100 \%$ of cave visits, irrespective of the season. Results from lab experiments show the pathogen's spores can remain viable on pieces of contaminated caving equipment under room temperature for at least 25 days, with no significant reduction in germination rates. This is concerning evidence indicating the potential for movement of viable $P$. destructans spores across countries and continents. Results further demonstrated that any type of regular washing can successfully remove the majority of $P$. destructans spores from several fabric types. Brushing complemented by washing in a 'washing machine' was slightly more effective than brushing alone, while a washing temperature of $50^{\circ} \mathrm{C}$ was more effective than temperatures of 30 and $40^{\circ} \mathrm{C}$. However, none of the methods herein tested fully removed $P$. destructans and hence they are not a substitute for decontamination. Since many cavers forgo washing equipment after surveys, and bat workers often visit several underground sites per day during monitoring activities without cleaning equipment in between sites, it is essential to raise awareness on this subject and introduce hygienic protocols for the prevention of pathogen pollution in underground sites.
\end{abstract}

Keywords: WNS, bats, cave management, emerging infectious diseases, pathogen pollution

Received 25 April 2020; Revised 27 August 2020; Accepted 27 August 2020

Citation: Zhelyazkova V., Hubancheva A., Radoslavov G., Toshkova N. and Puechmaille S.J., 2020. Did you wash your caving suit? Cavers' role in the potential spread of Pseudogymnoascus destructans, the causative agent of White-Nose Disease. International Journal of Speleology, 49 (2),149-159. Tampa, FL (USA) ISSN 0392-6672 https://doi.org/10.5038/1827-806X.49.2.2326

\section{INTRODUCTION}

Introduction of non-native pathogens into previously unoccupied areas, known as 'pathogen pollution' (Cunningham et al., 2003) is a serious threat to wildlife, and has the potential to cause emergent infectious diseases and local extinctions (e.g., Daszak et al., 2000; De Castro \& Bolker, 2005). Such is the case of White-Nose Disease (WND) in hibernating bats, responsible for one of the greatest mammalian mass mortalities in modern history (Puechmaille et al., 2011a; Frick et al., 2015). In line with the increasing rate of emergent fungal infections worldwide (Fisher et al., 2012), its causative agent is a fungus: the cave-dwelling species Pseudogymnoascus destructans (Lorch et al., 2011; Warnecke et al., 2012). The pathogen is considered native to Eurasia (Leopardi et al., 2015; Drees et al., 2017b) where it is not associated 
with mass morbidity or mortality (Puechmaille et al., 2010; Puechmaille et al., 2011b; Zukal et al., 2016; Fritze \& Puechmaille, 2018; Kovacova et al., 2018) and was only recently introduced to North America. First documented in 2006 in New York State (Reeder \& Turner, 2008; Veilleux, 2008), it is now confirmed in 38 U.S.A states and seven Canadian provinces, and estimated to have caused between 5.5 and 6.7 million bat deaths (U.S. Fish and Wildlife Service, 2020), thus significantly affecting both natural and agricultural ecosystems.

At short distances, bats migrating between roosts seem to be the main vector of $P$. destructans but long-distance dispersals (for instance, from Eastern to Western North America or from Europe to North America) are suspected to be human-mediated (Petit \& Puechmaille, 2015; Lorch et al., 2016). As $P$. destructans not only colonizes bat skin, its long term persistence in the hibernacula environment (Puechmaille et al., 2011b; Raudabaugh \& Miller, 2013; Reynolds et al., 2015; Fischer et al., 2020) may cause humans visiting underground sites to become potential vectors via their 'dirty' clothes and equipment. For example, Ballmann et al. (2017) reported the presence of $P$. destructans DNA on equipment used at WND-impacted sites and Reynolds \& Barton (2014) pointed out more than $1 \times 10^{6}$ fungal spores (across species) can be found on human footwear after a single cave visit. Additionally, Campbell et al. (2020) showed $P$. destructans can survive at temperatures above $20^{\circ} \mathrm{C}$ and be potentially transported by bats outside of cave hibernacula. However, no research has attempted to look at the frequency of occurrence in human-mediated spread of $P$. destructans.

Given the serious impact of WND to bat populations, related instructions for cavers' behaviour based on laboratory experiments (e.g., Puechmaille et al., 2011c; Shelley et al., 2013) were developed shortly after the disease outbreak in North America (the term cavers is used here for people utilizing caves / mines/underground sites; including bat researchers). National Decontamination Protocols adopted by the USA and Canada (U.S. Fish and Wildlife Service, 2020) advise 'all persons who come into contact with bats, their environments, and/or associated materials' to take precautions such as site-dedication of clothing and equipment, washing with laundry detergents and/or at temperatures above $50^{\circ} \mathrm{C}$, or disinfection using, alcohol, hydrogen peroxide, or chlorine bleach solution products. As a preventive strategy, cavers are also encouraged to follow these protocols when entering Australia (Wildlife Health Australia, 2019). In Europe, the European Federation of Speleology (FSE European Working Group on WNS, 2010) recommends cavers should reduce the number of visits to bat hibernacula, clean equipment with soap water when changing caving areas, and decontaminate equipment when traveling across continents. However, the role of humans as $P$. destructans vectors is not obvious to the average cave visitor. Thus, the lack of published evidence from the field partly hinders the application of present restrictions and limits their conservation effectiveness.
The aim of the present study is to fill the current knowledge gap in preventative actions or behaviours, and to demonstrate cavers' potential as $P$. destructans vectors. First, samples were collected from caving equipment used in underground sites to test for the presence and frequency of $P$. destructans spores on the equipment, and more importantly, spore viability. Second, lab experiments were conducted using deliberately contaminated pieces of caving equipment to trace $P$. destructans viability on the fabrics through time, while imitating typical storage conditions of such equipment. Lastly, an experimental test was performed to examine the effectiveness of common hygiene practices people most often apply while cleaning contaminated pieces of caving equipment in the absence of a $P$. destructans-decontamination protocol. The results demonstrate that human clothes/equipment can be a vector for viable $P$. destructans spores, though simple washing practices can significantly remove most spores. Finally, we advocate that simple preventive practices, if adopted at a large scale, by a large majority of cavers, would be more effective than stricter practices followed by few, and that education on pathogen pollution is greatly needed, irrespective of the presence or absence of an immediate crisis.

\section{MATERIALS AND METHODS}

\section{Isolating $\boldsymbol{P}$. destructans from caving equipment}

Sample collection

Swabs from caving equipment were collected during two consecutive field seasons (2017 and 2018) in Bulgaria. Sampling sites included two limestone caves, Ivanova voda (N41.89, E24.88) and Balabanova dupka (N43.13, E23.04), where $P$. destructans presence was previously confirmed by culture and genetic analysis both on bats and cave walls (Zhelyazkova \& Puechmaille, unpublished data). In both caves, passages are present that require climbing and/or crawling. Thus, contact between clothes and cave substratum is inevitable, which is typical for caves that are not tourist destinations. During each visit, 5 samples were taken from researchers' equipment (caving suits, gloves, boots, harnesses, and bags; previously washed with soap and water) before entering the cave to control for $P$. destructans contamination from previous caving trips. Five more samples were taken from the same pieces of equipment (and the same area of those pieces of equipment) upon exiting the cave (Supplemental Table). A sample consisted of approximately a $10 \mathrm{~cm}^{2}$ area, swabbed using a dry sterile polyester swab (COPAN Diagnostics, Murrieta) that was then placed in an empty sterile Eppendorf tube and taken to the lab for cultivation. When swabbing a caving boot, the upper part of the boot was chosen to avoid over-collecting of mud (Fig. 1A). When swabbing a caving suit, the areas of the knees or the elbows were chosen as they more often come into contact with cave walls (Fig. 1B). A total of 100 samples were collected from 10 trips (10 samples per trip, 5 on entry, 5 on exit). Three samples were lost in the field and did not reach the lab. 


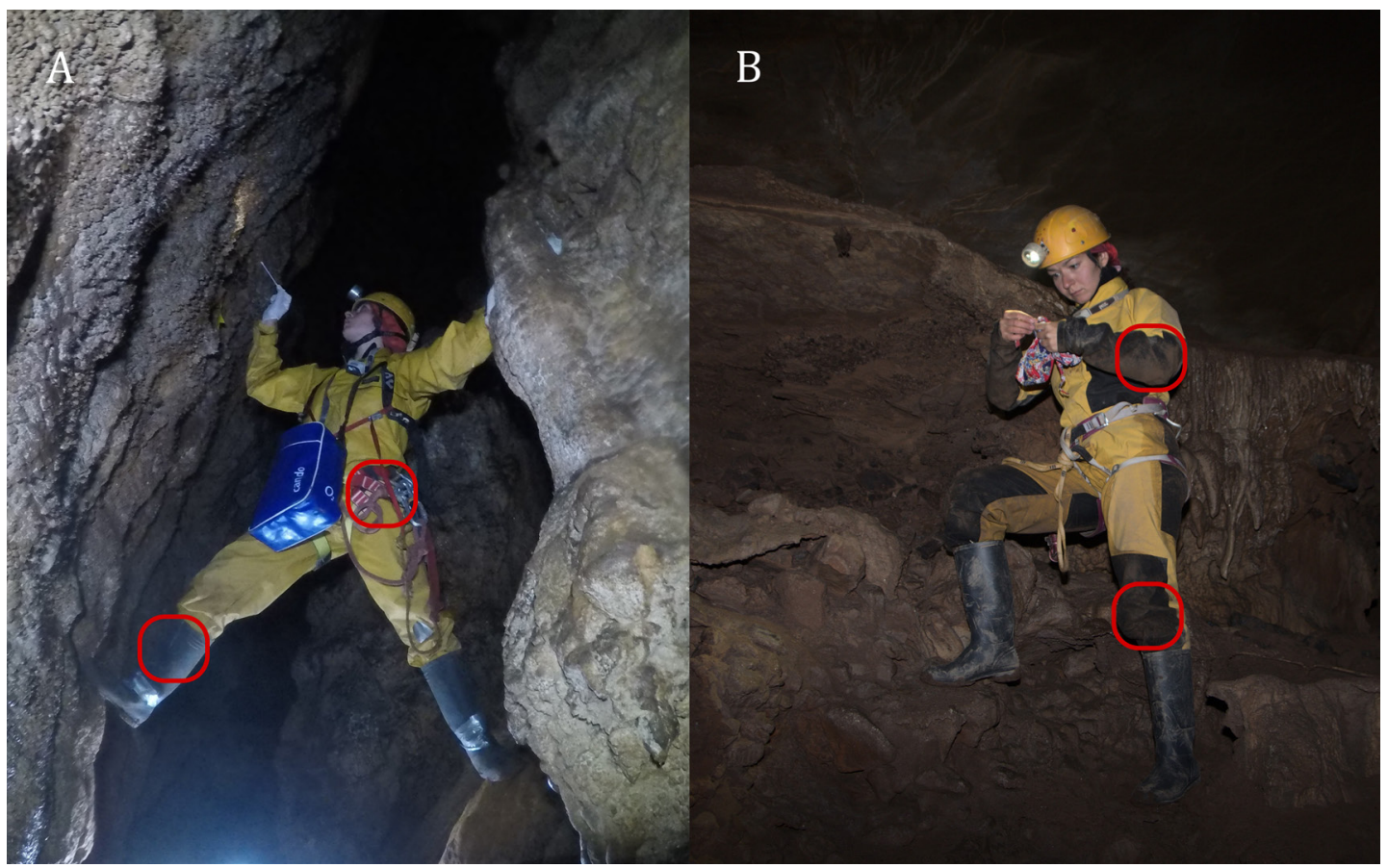

Fig. 1. Work in Ivanova voda (A) and Balabanova dupka (B) during which samples were collected from caving equipment. Swabbed areas of caving equipment are marked with red squares. Photographs by Krum Sirakov.

\section{Cultures}

To evaluate the presence of viable $P$. destructans spores in a sample, cultures were used instead of the classic DNA-based detection methods (e.g., qPCR). DNA-based detection methods are informative for the presence and quantity of $P$. destructans DNA in a sample but are uninformative concerning viability. Swabs were plated on DPYA (Dextrose Peptone Yeast extract Agar) growth medium prepared as described in Vanderwolf et al. (2016). The swab was dabbed 5 times onto the plate, then $100 \mu \mathrm{l} \mathrm{dH}_{2} \mathrm{O}$ added, and spread with a sterile microbiological spatula. Dishes were sealed with parafilm and stored inverted in the dark at $4^{\circ} \mathrm{C}$. Colonies showing a morphology similar to $P$. destructans were isolated and then genetically confirmed as $P$. destructans as they successfully amplified for a panel of 18 microsatellites and two mating-type markers (Drees et al., 2017a; Dool et al., 2020).

\section{II. $P$. destructans spore viability on caving equipment}

A schematic of the spore viability experiment is presented in Figure 2.

\section{Material preparation}

To quantify $P$. destructans spore viability on caving equipment, three of the most popular materials used by speleologists were tested: cordura fabric for caving suits (Yana, Sofia), PVC fabric for caving suits (Lanjoff, Sofia), and a $9 \mathrm{~mm}$ nylon rope (Beal, Sofia). The fabrics were cut into $2 \mathrm{~cm}^{2}$ squares, and the rope into $2 \mathrm{~cm}$ long pieces. To create sterile conditions, all materials were autoclaved prior to the experiment, which did not visibly change their characteristics. Cave sediments from Svinskata dupka cave (N43.08 E23.38) were collected, autoclaved, and manually homogenized prior to the experiment. Sediments were sticky, containing more clay than sand. As $P$. destructans isolates may
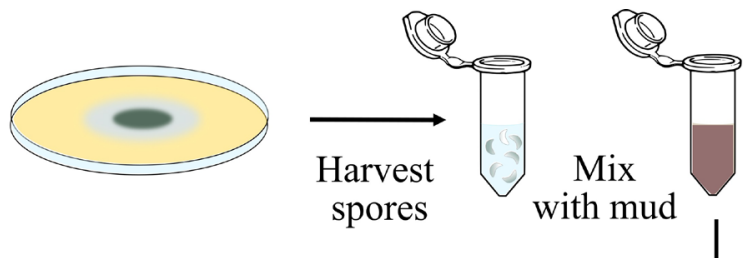

Contaminate equipment

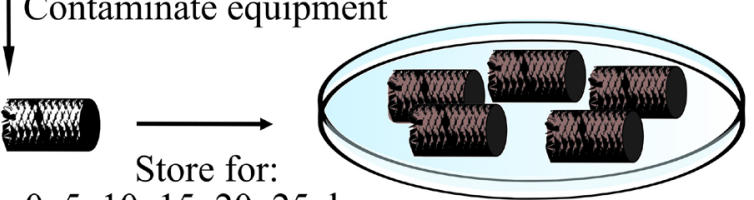

$0,5,10,15,20,25$ days

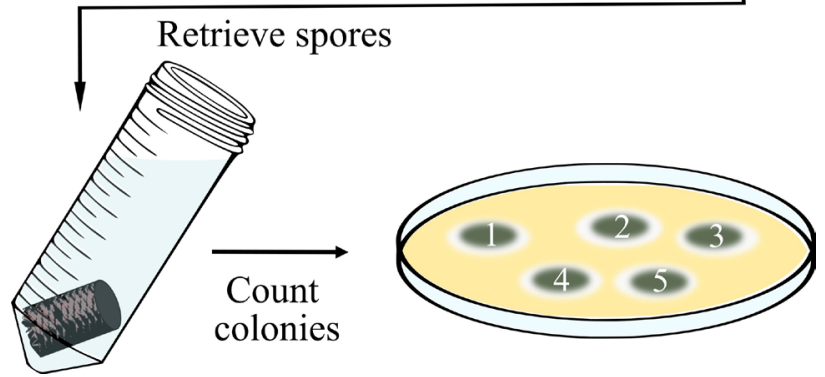

Fig. 2. Schematic of $P$. destructans spore viability on caving equipment experiment with nylon rope as an example. The same procedure was performed on both cordura and PVC pieces.

vary in their survival and viability patterns, a mix of cultures in a spore solution was used to investigate the general species characteristic. P. destructans spore solution was prepared using a mixture of three randomly selected cultures originating from bats in Ivanova voda (Gd_2219-baa, Gd_2225-aaa, Gd_2227-aaa; The isolates can be obtained from the corresponding author upon request), the identity of which had been previously confirmed by microsatellite genetic analysis as described above. Fungal material (including hyphae and spores) was scraped off the plate and mixed with $\mathrm{dH}_{2} \mathrm{O}$ in a 2-ml Eppendorf tube and homogenized manually and using a vortex. 
At the time of scraping, cultures were approximately 4 months old. Spore concentration was determined using a Bürker cell-counting chamber and the average of 10 counts was used. Finally, dilutions were made to achieve a concentration of $10^{6}$ spores $/ \mathrm{ml}$.

\section{Contamination procedure}

A total of 180 pieces of equipment (60 per material type) were used for the spore viability experiment. For cordura and PVC fabrics, approximately $50 \mathrm{mg}$ of sediment were placed in the center of each piece and $100 \mu 1$ of spore solution added on top. Sediment and spore solution were mixed manually for 30 seconds using a small metal spoon and distributed evenly over the whole surface of the fabric piece. For the rope, the same quantities of sediment and spore solution were used, but the sediment was wet prior to applying it to the rope. All procedures were performed under sterile conditions and spore solution was homogenized by vortexing prior to pipetting.

\section{Storage conditions}

All pieces of equipment were divided into 2 storage groups. In Group 1, pieces were left to dry for 5 hours after contamination (until they were visibly completely dry). They were stored in an illuminated space at room temperature $\left(20\right.$ to $\left.23^{\circ} \mathrm{C}\right)$ imitating equipment that was left to dry without washing. In Group 2, pieces of equipment were left wet after contamination. They were stored in a bag, in the dark, at the same temperature imitating equipment left in a backpack. To avoid contamination with airborne microbes, which would hamper the isolation of viable $P$. destructans spores, samples from both groups were placed in empty sterile Petri dishes sealed with parafilm. For Group 1, 9-cm dishes were used, and for Group 2, 6-cm dishes were used to keep humidity higher. Five pieces (=replicates) of equipment were placed in each dish. In the smaller dishes, different pieces were slightly touching each other.

\section{Spore retrieval and plating}

Five replicates (each randomly taken from a different storage dish) of each of the three materials from each storage group (dry \& wet) were taken for spore retrieval every 5 days over a period of 25 days starting from day 0 of the experiment (Fig. 2). This resulted in 180 ( 3 materials * 5 replicates * 2 storage conditions * 6 storage periods) pieces of material. A single piece of contaminated equipment (each piece was used only once) was put in a sterile $50-\mathrm{ml}$ tube filled with $10 \mathrm{ml}$ of ultrapure water using sterile tweezers, and vortexed for 20 seconds. The resulting solution was plated on 9-cm Petri dishes with DPYA growth medium. For the culture, two different plating dilutions were used - the first one using $100 \mu \mathrm{l}$ of the solution, and the second one using $500 \mu 1$ of solution. Two dilutions were used as it was not possible to have precise predictions regarding the number of $P$. destructans spores potentially germinating over the course of the experiment. Dishes were sealed with parafilm and stored inverted in the dark at $4^{\circ} \mathrm{C}$. Fungal colonies (CFU's) were counted manually after 2 weeks.

\section{Cleaning effectiveness}

A schematic of the cleaning effectiveness experiment is presented in Figure 3. PVC fabric was excluded from this test as the previous spore viability experiment detailed above showed a very low survival rate of $P$. destructans on PVC in wet conditions (see Results section). Thus, it was assumed any washing treatment including water would completely kill the fungus on PVC. Pieces of cordura fabric and rope were prepared and covered with $P$. destructans contaminated sediment as described for Group 2 above (i.e., 'wet'). Contaminated fabrics were stored overnight in empty sterile Petri dishes sealed with parafilm (to avoid airborne contamination) at room temperature and cleaned the following day. Five replicates per material were used for each cleaning treatment and five replicates that were contaminated but not cleaned served as controls. Autoclaved tap water was used for all treatments.

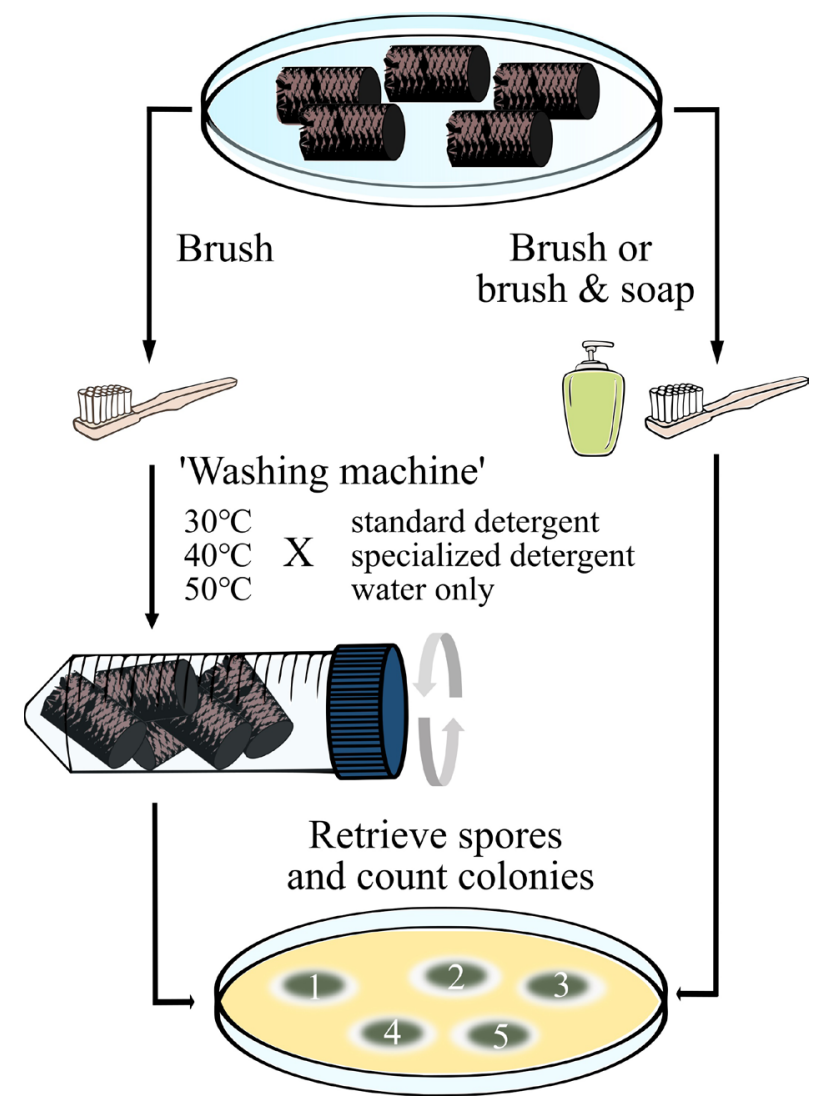

Fig. 3. Schematic of the cleaning effectivness experiment with nylon rope as an example. The same procedure was performed for cordura fabric pieces. Equipment contamination, spore retrieval, and plating were performed as shown in Figure 2.

\section{Handwashing}

A hygiene practice commonly used by cavers consists of brushing dirty equipment in a bathtub or a river (usually with cold water) to physically remove the most prominent mud from the materials. To imitate this under laboratory conditions, a sterile toothbrush was used to remove $P$. destructans contaminated sediment from each piece of the tested equipment. Five pieces were put together in a 9-cm Petri dish filled with water at room temperature. Each piece was brushed for 10 seconds, then rinsed with $1 \mathrm{ml}$ of water.

More cautious cavers who are informed about the risk of pathogen pollution may also add soap to 
the water before brushing their equipment, as this recommendation is part of a protocol by the European Federation of Speleology regarding the prevention of $P$. destructans movement within Europe (FSE European Working Group on WNS, 2010). To test this protocol, 5 pieces of contaminated equipment were placed in a Petri dish as described above. Each piece was first cleaned with a sterile toothbrush for 5 seconds, next with a brush dipped in common liquid soap (Palmolive, Sofia) for 10 seconds, and finally rinsed with $3 \times 1$ $\mathrm{ml}$ of water, which was needed to completely remove the soap.

\section{'Washing machine'}

To save time, many cavers choose to wash their equipment in a washing machine after brushing off the mud from the dirtiest parts. Most often, only water is used but, in some cases, detergents are also added. To imitate this scenario, the pieces of contaminated equipment were first brushed for 5 seconds as described above. The washing machine effect was imitated by $50-\mathrm{ml}$ tubes placed in a roller incubator (with constant temperature maintained). Five pieces of equipment were placed in each tube and filled with water: $40 \mathrm{ml}$ for the tubes containing cordura fabric and $30 \mathrm{ml}$ for tubes containing rope. Three different temperatures $\left(30^{\circ} \mathrm{C}, 40^{\circ} \mathrm{C}\right.$, and $\left.50^{\circ} \mathrm{C}\right)$ were tested and for each temperature treatment, three tubes were prepared: water only, water and common liquid detergent (Ariel, Sofia), and water and specialized detergent for mountain equipment (NST Wash, Sofia). A volume of $200 \mu \mathrm{l}$ of detergent was added to $40 \mathrm{ml}$ of water, which approximated detergent to water ratio recommended by manufacturers. Temperatures above $50^{\circ} \mathrm{C}$ were not tested because they have been tested in other studies (Shelley et al., 2013) and because washing of life-supporting equipment (such as ropes and harnesses) at high temperatures is not generally practiced. Only two detergent types were tested as the aim of the present experiment was not to test market products, but simply to test if the addition of commonly used detergents significantly improved removal of $P$. destructans. All test tubes were rolled in the roller incubator set at the particular temperature $\left(30^{\circ} \mathrm{C}, 40^{\circ} \mathrm{C}\right.$, or $\left.50^{\circ} \mathrm{C}\right)$ for 30 minutes, then water in the tubes was changed 4 times to imitate rinsing.

Spore retrieval and plating were performed immediately after all treatments as described in the previous section (Experiment II). Fungal colonies were counted manually after 2 weeks.

\section{Statistical analysis}

Statistical analyses were performed in $\mathrm{R}$ Studio (version 3.6.2). General linear models with a negative binomial distribution were used. Candidate models included all combinations of the explanatory variables, with or without interaction as specified below depending on the dataset. For each dataset, the Akaike information criterion with a correction for small sample sizes (AICc) was used to compare the fit of models. Subsequently, multimodel inferences were used for model averaging, whereby the model-averaged confidence intervals (95\% CI) of the coefficients were calculated based on the cumulative weights of all models including the term. Explanatory variables with $95 \%$ CI not encompassing zero were considered to have a meaningful impact on the response variable.

For the spore viability experiment, the number of colonies enumerated in the dishes ( $P d$ spore count) was used as a response variable, and the number of days of storage on the fabrics $(0,5,10,15,20$, and 25), material contaminated (cordura, rope, or PVC), and storage conditions (wet or dry) as explanatory variables.

For the cleaning effectiveness experiment, the type of washing (control vs 'washing machine' and handwashing), and material contaminated were used as explanatory variables. For the 'washing machine' scenario, temperature $\left(30,40\right.$, and $\left.50^{\circ} \mathrm{C}\right)$, detergent (water only vs specialized and standard detergent), and material contaminated were used as explanatory variables. For the handwashing part, detergent (brush only vs brush \& soap), and material contaminated were used as explanatory variables. Again, the number of colonies enumerated in the dishes $(P d$ spore count) was used as a response variable. For both experiments, the count data from dishes where $100 \mu 1$ of spore solution was plated were used as enumeration was more reliable due to less plate filling. Increases or decreases in germination of $P$. destructans spores for different treatments are presented as an incidence rate ratio (in comparison to the control group). Graphs were prepared with ggplot2 (Wickham, 2016).

\section{RESULTS}

\section{Isolating $\boldsymbol{P}$. destructans from caving equipment}

A total of $12 P$. destructans cultures were obtained (Table 1) from 9 of 25 samples collected after visits to Ivanova voda (Supplemental Table). At least 1 culture was obtained from each of the 5 field trips. From Balabanova dupka, a total of $12 P$. destructans cultures were obtained (Table 1) from 5 of 24 samples (one sample was lost in the field) collected after visits to the cave (Supplemental Table). Out of 5 field trips, 3 returned samples positive for $P$. destructans. No $P$. destructans was isolated from any of the control samples collected before cave entry.

\section{II. $\boldsymbol{P}$. destructans viability on caving equipment}

Storage time (from 0 to 25 days, tested every 5 days) of the caving equipment under room temperature did not lead to a significant reduction in $P$. destructans germination rate (Coefficient [95\% $\mathrm{CI}]$ : 0.0129 [-0.0116-0.0376]; Fig. 4). It is important to highlight significant differences in overall viability depending on the material used. When using cordura fabric as the reference, the estimates of $P$. destructans spore recovery for rope and PVC fabric pieces were 52 and 69\% smaller respectively (rope: -0.9100 [-1.3746 - -0.4455]; PVC: -1.3519 [-1.8650 - -0.8388]). Interestingly, in both dry and wet conditions, a peak in spore germination was observed on cordura fabric pieces after 10 to 15 days of storage. The interaction between storage condition (dry versus wet) and the material type was only significant for 
Table 1. Samples positive for the presence of $P$. destructans, collected from various caving equipment substrates after visiting Ivanova voda and Balabanova dupka caves in 2017 and 2018. Species identity of positive cultures was confirmed by microsatellite genetic analysis as described by Dool et al. (2020).

\begin{tabular}{|c|c|c|c|c|}
\hline Sample & P. destructans isolate & Site & Date & Substrate \\
\hline 20170318_IVA_C_42 & Gd_02169-aa & Ivanova voda & $18 / 03 / 2017$ & cordura suit \\
\hline 20170409_GBL_C_62 & Gd_02181-aa & Balabanova dupka & $09 / 04 / 2017$ & caving bag \\
\hline 20170409_GBL_C_64 & Gd_02182-aа & Balabanova dupka & $09 / 04 / 2017$ & cordura suit, leg \\
\hline 20170609_GBL_C_61 & Gd_02204-aa & Balabanova dupka & 09/06/2017 & PVC suit, leg \\
\hline 20170617_IVA_C_50 & Gd_02229-aa & Ivanova voda & $17 / 06 / 2017$ & harness \\
\hline 20170617_IVA_C_51 & Gd_02230-aa & Ivanova voda & $17 / 06 / 2017$ & caving gloves \\
\hline 20170617_IVA_C_51 & Gd_02230-ab & Ivanova voda & $17 / 06 / 2017$ & caving gloves \\
\hline 20171023_IVA_C_38 & Gd_02247-aa & Ivanova voda & $23 / 10 / 2017$ & cordura suit, sleeve \\
\hline 20180317_IVA_C_36 & Gd_02254-aa & Ivanova voda & $17 / 03 / 2018$ & cordura suit, left leg \\
\hline 20180317_IVA_C_36 & Gd_02254-ab & Ivanova voda & $17 / 03 / 2018$ & cordura suit, left leg \\
\hline 20180317_IVA_C_37 & Gd_02255-aa & Ivanova voda & $17 / 03 / 2018$ & cordura suit, left sleeve \\
\hline 20180513_GBL_C_68 & Gd_02275-aa & Balabanova dupka & $13 / 05 / 2018$ & caving boot \\
\hline 20180513_GBL_C_68 & Gd_02275-ab & Balabanova dupka & $13 / 05 / 2018$ & caving boot \\
\hline 20180513_GBL_C_68 & Gd_02275-ac & Balabanova dupka & $13 / 05 / 2018$ & caving boot \\
\hline 20180513_GBL_C_68 & Gd_02275-ad & Balabanova dupka & $13 / 05 / 2018$ & caving boot \\
\hline 20180513_GBL_C_68 & Gd_02275-ae & Balabanova dupka & $13 / 05 / 2018$ & caving boot \\
\hline 20180513_GBL_C_70 & Gd_02276-aa & Balabanova dupka & $13 / 05 / 2018$ & cordura suit, sleeve \\
\hline 20180513_GBL_C_70 & Gd_02276-ab & Balabanova dupka & $13 / 05 / 2018$ & cordura suit, sleeve \\
\hline 20180513_GBL_C_70 & Gd_02276-ac & Balabanova dupka & $13 / 05 / 2018$ & cordura suit, sleeve \\
\hline 20180513_GBL_C_70 & Gd_02276-ae & Balabanova dupka & $13 / 05 / 2018$ & cordura suit, sleeve \\
\hline 20181011_IVA_C_39 & Gd_02658-aa & Ivanova voda & $11 / 10 / 2018$ & cordura suit knee \\
\hline 20181011_IVA_C_41 & Gd_02659-aa & Ivanova voda & $11 / 10 / 2018$ & harness (step) \\
\hline 20181011_IVA_C_41 & Gd_02659-ab & Ivanova voda & $11 / 10 / 2018$ & harness (step) \\
\hline 20181011_IVA_C_42 & Gd_02660-aа & Ivanova voda & $11 / 10 / 2018$ & sample bag \\
\hline
\end{tabular}

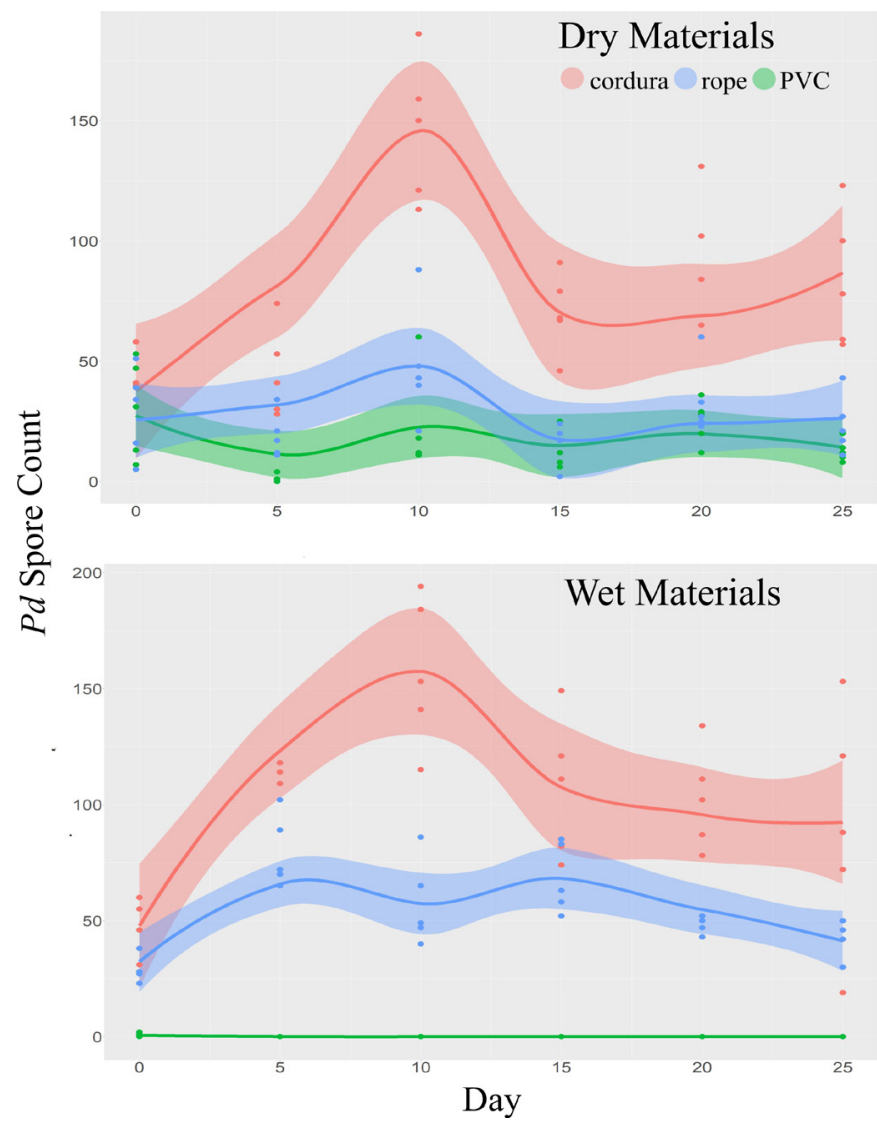

Fig. 4. Visual representation (Loess smoothing factor with $95 \%$ confidence interval around the mean of the smoothed loess regression line) of $P$. destructans viability on caving equipment from 0 to 25 days. Germination rates were not significantly reduced with time, but overall viability was significantly influenced by the materials used. The interaction between the storage conditions (wet or dry) and PVC was significant. the PVC fabric $(-4.9564[-6.8718--3.0411])$ : on dry $\mathrm{PVC}, P$. destructans remained viable till the end of the experiment (25 days), but on wet PVC fabric, $P$. destructans did not survive after the first 5 days (Fig. 4).

\section{Effectiveness of cleaning}

When compared to the control group, a significant reduction in the number of $P$. destructans spores on the fabrics could be seen after both 'washing machine' treatment (decrease of 95\%, -3.0169 [-4.2745--1.7592]) and handwashing (decrease of 94\%, Coefficient [95\% CI]: -2.7493 [-4.2215--1.2770]) (Fig. 5). In the washing machine' treatments, higher temperature improved cleaning effectiveness $\left(40^{\circ} \mathrm{C}, 55 \%\right.$ decrease in $P$. destructans spores compared to $30^{\circ} \mathrm{C},-0.8055[-1.2684$ - -0.3425]; $50^{\circ} \mathrm{C}, 80 \%$ decrease in $P$. destructans spores compared to $30^{\circ} \mathrm{C},-1.6085$ [ -2.1406 - -1.0764]). Adding a detergent, both standard and specialized also contributed to the reduction of germinating P. destructans spores by 97 and $82 \%$ respectively compared to the use of water only (standard: -3.5583 [-4.3665 - -2.7501]; specialized: -1.7023 [-2.1575 $-1.2470])$. Material type was a significant factor, the rope being cleaned less successfully than the cordura fabric $(256 \%$ increase in $P$. destructans germination, 1.2694 [0.8445 - 1.6942]). In handwashing, the treatment type (i.e., use of water or soap with the brush) was not significant $(-0.4294[-1.1474-0.2887])$. As in the washing machine experiment, the rope was again cleaned less successfully compared to the cordura fabric $(130 \%$ increase in $P$. destructans germination, $0.8197[0.1081-1.5312])$. 


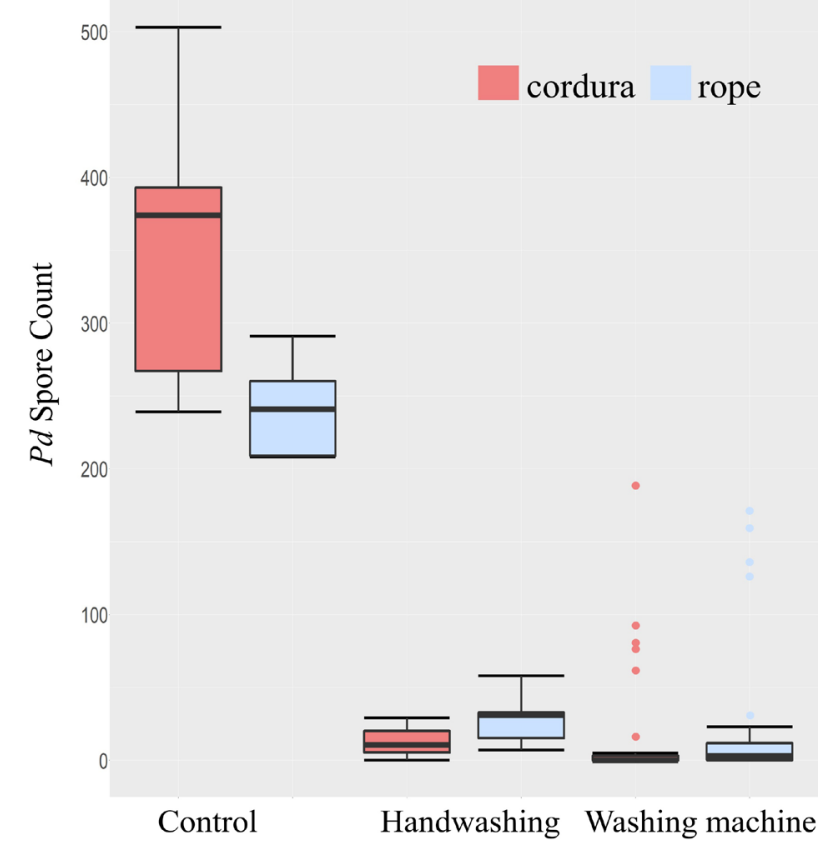

Fig. 5. Effectiveness of cleaning or hygiene practices. Both handwashing and washing in a 'washing machine' lead to significant reduction in $P$. destructans spore counts on caving equipment, with nylon rope being cleaned less successfully than cordura fabric. For each boxplot, the box represents the 0.25 quantile, median and 0.75 quantile. On either side of the box, the whiskers extend to the minimum and maximum. To showcase possible outliers, whiskers were shortened to a length of 1.5 time the box length.

\section{DISCUSSION}

\section{Cavers as effective vectors of $\boldsymbol{P}$. destructans}

Results of the present research clearly demonstrate that during human visitation to caves, clothing and equipment can become contaminated with viable $P$. destructans spores, irrespective of fabric types or time of the year (before or after bat hibernation). Despite the limited surface area swabbed and the relatively low number of samples collected per trip, viable $P$. destructans was cultured following almost every cave visit. Assuming that a caving suit is made of roughly $2 \mathrm{~m}^{2}$ of fabric, 1-2 P. destructans spores isolated from an area of $10 \mathrm{~cm}^{2}$ may indicate the potential for hundreds of spores to be present on a whole suit. Additionally, given that the cultivation method does not detect all viable material present in a sample, the true number of $P$. destructans spores present on caving clothes may be underestimated. The number of $P$. destructans spores on caving equipment is surely partly dependant on the contact rate between the equipment and the environment, which varies between sites, between cavers within a site and between areas of the same caving suit. Furthermore, the amount of $P$. destructans DNA drastically varies between and within sites as well as within seasons (Hoyt et al., 2020). For example, within sites, variations can be related to the type of sediments, proximity to bat colonies, and distance from the entrance or height from the floor (Verant et al., 2018). Thus, variation in the amount of viable material can also be expected. Irrespective of these variations which are ubiquitous under field conditions and beyond the scope of the present study, viable $P$. destructans was isolated from cavers' equipment upon exiting underground sites, demonstrating that cavers can potentially spread $P$. destructans between sites.

\section{Importance of $\boldsymbol{P}$. destructans viability on caving equipment}

Results from the lab experiment further showed that $P$. destructans spores can germinate after storage on dirty fabrics (cordura, nylon rope, and PVC) for at least 25 days at room temperature under both wet and dry conditions (except for wet PVC). This is ample time for human travel to occur across countries and continents and effectively spread the pathogen between geographically distant sites. $P$. destructans viability was not investigated for longer than 25 days and results obtained in the present experiment might vary depending on fungal isolates, cave sediment, brands of equipment, or storage conditions. However, the observed trends should be robust to such variations and the marginal decays in germination rates suggest that some spores might even remain viable for several months or longer on caving equipment. This is supported by another experiment (Fischer et al., 2020) with contaminated concrete blocks where $P$. destructans spores stayed viable for at least two years at $10^{\circ} \mathrm{C}$, even in the absence of nutrients. Based on model estimates, Reynolds et al. (2015) speculate that $P$. destructans populations can survive in sediments from bat hibernacula for decades, and studies in other species indicate that fungal spores are among the most stress-resistant eukaryotic cells described to date (Wyatt et al., 2013). As reaching a suitable habitat seems to be the main factor for a successful alien species invasion (Skarpaas et al., 2009), caving equipment could be a particularly good $P$. destructans vector, being transported not between random sites but between caves (or mines) that often offer similar environmental conditions across the globe. In many countries, caving and cave tourism are becoming increasingly popular activities, supported by more affordable international travel, thus greater research and awareness on the subject are needed.

\section{Significance of materials}

Regarding the difference in $P$. destructans survival on tested materials, a detailed interpretation of the results requires further investigation. The peak in spore germination observed on cordura fabric after 10 to 15 days of storage is consistent with other $P$. destructans survival/viability experiments (Fischer et al., 2020). Many factors have been demonstrated to stimulate or inhibit fungal spore germination (e.g., Wyatt et al., 2013), however, there is not enough information to explain the difference in $P$. destructans germination curves on cordura fabric and nylon rope. The almost $100 \%$ mortality of $P$. destructans spores on wet PVC suit pieces could be explained by the proven toxicity of plasticized PVC leaking in water (Lithner et al., 2012). Whether this should be considered as a promise for $P$. destructans-killing caving equipment or as a warning for potential sources of underground water pollution, is a worthy question for further research. 


\section{Broader relevance to pathogen pollution in caves}

The overall conclusion that humans act as vectors of $P$. destructans spores is likely valid for many if not most species of cave fungi. These include bat specific pathogens such as Trichophyton redellii, currently not associated with mortality events but still poorly investigated with reports only from North America (Lorch et al., 2015), or human specific pathogens such as Histoplasma capsulatum, the most frequent cause of fungal respiratory infection with a potentially lethal outcome (Deepe, 2015). Over 1,000 described species of fungi, slime moulds, and yeasts have been documented in caves and mines worldwide (e.g., Vanderwolf et al., 2013) but total species count is expected to be much higher. For example, based on sampling at only four caves and two mines from New York, Zhang et al. (2014) identified 248 Operational Taxonomic Units of fungi, however the species accumulation curve showed no sign of reaching a plateau. Hence, the number of fungal species per site is likely in the hundreds, if not thousands, and all these may be capable of adhering to caving clothing and equipment, especially when coated in cave sediment. Therefore, the potential risk of spreading cave microbes, regardless of known pathogenicity, should be carefully considered by all visitors to underground sites anywhere on the globe.

\section{Disinfection procedures and hygiene}

Not surprisingly, the experiments from the current study revealed that hygiene is an important factor for limiting $P$. destructans load on caving equipment and thus reduces the risk of pathogen pollution in caves. They complement the results obtained by Shelley et al. (2013) who tested multiple detergents and exposure temperatures that could kill $P$. destructans on fabrics. The most appropriate hygienic technique recommended by Shelly et al. (2013) was immersion in water above $50^{\circ} \mathrm{C}$ for at least 25 minutes and/or applying a list of commercially available chemicals, which demonstrated an effective kill rate greater than $99.995 \%$. The aim of the present study was not to improve this rate, but to examine regular hygiene practices used by cavers in Europe and to test whether such practices approach decontamination effectiveness. In accordance to Shelley et al., the present results showed that simply brushing off the mud from caving clothes and equipment greatly reduced the amount of $P$. destructans spores on the fabrics with an average of 95.3 of spores being removed from the cordura fabric pieces and an average of $85.1 \%$ being removed from the nylon rope. Increased time of washing, adding detergents, and/or raising the temperature further improved cleaning effectiveness. The best results were obtained by washing with standard detergent at $50^{\circ} \mathrm{C}$, which led to an average of $99.8 \%$ of $P$. destructans spores being removed from the cordura fabric pieces and an average of $98.7 \%$ being removed from the nylon rope. The difference between tested materials may be due to the porous texture of the rope, which would hamper the physical removal of contaminated mud particles. It is also important to note that while washing with standard laundry detergents at a temperature of $50^{\circ} \mathrm{C}$ or above is appropriate for caving suits, this is not true for life-supporting equipment such as ropes and harnesses. For ropes and harnesses, manufacturers usually recommend washing at temperatures up to $30^{\circ} \mathrm{C}$ either with no detergent or with specialized detergent only. Caving rope is not typically washed using a washing machine and specialized equipment detergents are often cost prohibitive, thus it is realistic to assume that ropes and harnesses are only being washed with water at room temperature, and this treatment showed the lowest relative effectiveness in $P$. destructans removal in the present study.

\section{Practical advice for cavers' behaviour}

Given the evidence of potential transport of $P$. destructans and/or other species of cave microbes by cavers via clothes and equipment, we recommend that hygiene practices (that are neither difficult nor expensive) to clean clothes and equipment occur after every visit to an underground site at any point on the globe. Although this will not completely prevent pathogen pollution in caves or elsewhere, it can drastically reduce propagule pressure, measured as the number of alien individuals transported and the number of introduction events - overall reducing the chance of successful establishment and invasive population success (Lockwood et al., 2005). However, it is important to emphasize that reducing $P$. destructans load on caving equipment does not necessarily eliminate it, and that hygiene is not a substitute for decontamination. Therefore, existing decontamination protocols are still necessary when visiting sites of significant risk (e.g., sites in the USA and Canada) or when traveling to remote sites where the consequences of bringing alien microflora are not known (Zhelyazkova et. al., 2019). Regarding lifesupporting caving equipment that cannot be properly decontaminated, site-dedication (or region-dedication) would be the most appropriate option, especially for long distance and international travel.

\section{Future perspectives}

As the rate of biological invasions worldwide continues to increase (Hulme, 2009) and the consequences of such invasions are sometimes seen a century later (Essl et al., 2011), one cannot be too cautious when tackling the subject. To manage pathogen pollution (including but not limited to $P$. destructans and WND) in caves and elsewhere, a combination of both reactive (e.g., following specific decontamination protocols and locally adapted recommendations) and preventive (e.g., good hygiene) strategies should be considered. Of particular importance is communication with the target public as any measures, reactive or preventive, can only be effective if they are understood and accepted by the majority of communities. As most of the caving clubs accept new members after they complete a specialized course, it would be practical if pathogen pollution prevention could be included in the curriculum of such programs. Practicing hygienic techniques on equipment should be a normalized behaviour after every cave visit and reviewing potential 
risks for human and environmental health should become an obligatory part of expedition preparation. Additionally, it is important to distribute existing cleaning/decontamination protocols outside their countries of origin, evaluate the degree of awareness on the subject among people involved in caving activities, and assess the distribution and application of such recommendations within the caving community. We are convinced that conservation questions such as pathogen pollution prevention should go further than localized academic pursuits and become a mutual responsibility of our society in this time of globalization.

\section{ACKNOWLEDGMENTS}

The authors would like to thank Nicola Fischer for her advice regarding experimental design and genotyping $\mathrm{Pd}$ samples, and Marina Zaharieva for her laboratory assistance. We are also grateful to Alexander Lazarov, Krum Sirakov, Stoyan Goranov, Tsetan Ostromsky, and all volunteers who participated in sample collection, and anonymous reviewers for their valuable comments on our manuscript. Special thanks to Corinna Pinzari for proofreading our text and to Stanimira Deleva for popularizing our research findings among the caving community. This research was funded by the National Geographic Society [WW201ER-17, awarded to VZ], the Bulgarian Academy of Sciences, and the Deutsche Forschungsgemeinschaft [PU 527/2-1, awarded to SJP].

Authorship statement: VZ and SJP conceived the study. VZ and SJP designed the study with input from $\mathrm{AH}, \mathrm{GR}$ and NT. VZ, AH, and NT organised fieldwork and collected the samples. VZ performed the experiments. GR provided lab space, consumables and technical assistance. VZ and SJP analyzed the data and wrote the paper with input from all authors.

\section{REFERENCES}

Ballmann, A.E., Torkelson, M.R., Bohuski, E.A., Russell, R.E., Blehert, D.S., 2017. Dispersal hazards of Pseudogymnoascus destructans by bats and human activity at hibernacula in summer. Journal of Wildlife Diseases, 53, 725-735.

https://doi.org/10.7589/2016-09-206

Campbell, L.J., Walsh, D.P., Blehert, D.S., Lorch, J.M., 2020. Long-term survival of Pseudogymnoascus destructans at elevated temperatures. Journal of Wildlife Diseases, 56, 278-287.

https://doi.org/10.7589/2019-04-106

Cunningham, A.A., Daszak, P., Rodríguez, J.P., 2003. Pathogen pollution: Defining a parasitological threat to biodiversity conservation. Journal of Parasitology, 89, 78-83.

Daszak, P., Cunningham, A.A, Hyatt, A.D., 2000. Emerging infectious diseases of wildlife threats to biodiversity and human health. Science, 287, 443-449. https://doi.org/10.1126/science.287.5452.443

De Castro, F., Bolker, B., 2005. Mechanisms of diseaseinduced extinction. Ecology Letters, 8, 117-126. https://doi.org/10.1111/j.1461-0248.2004.00693.x

Deepe, G.S., 2015. Histoplasma capsulatum (Histoplasmosis). In: Bennett, J.A., Dolin, R., Blaser,
M.J. (Eds), Principles and practice of infectious diseases, Philadelphia, PA, p. 2949-2962.

Dool, S., Altewischer, A., Fischer, N.M., Drees, K.P., Foster, J.T., Fritze, M., Puechmaille, S.J., 2020. Mating type determination within a microsatellite multiplex for the fungal pathogen Pseudogymnoascus destructans, the causative agent of White-nose disease in bats. Conservation Genetics Resources, 12, 45-48. https://doi.org/10.1007/s12686-018-1064-6

Drees K.P., Lorch J.M., Puechmaille S.J., Parise K.L., Wibbelt G., Hoyt J.R., Sun K., Jargalsaikhan A., Dalannast M., Palmer J.M., Lindner D.L., Kilpatrick A.M., Pearson T., Keim P., Blehert D.S., Foster J.T., 2017b. Phylogenetics of a fungal invasion: Origins and widespread dispersal of White-nose syndrome. mBio, 8, e01941-01917.

https://doi.org/10.1128/mBio.01941-17

Drees, K.P., Parise, K.L., Rivas, S.M., Felton, L.L., Puechmaille, S.J., Keim, P., Foster, J.T., 2017a. Characterization ofmicrosatellitesin Pseudogymnoascus destructans for White-nose syndrome genetic analysis. Journal of Wildlife Diseases, 53, 869-874.

https://doi.org/10.7589/2016-09-217

Essl, F., Dullinger, S., Rabitsch, W., Hulme, P.E., Hülber, K., Jarošỉ, V., Kleinbauer, I., Krausmann, F., Kühn, I., Nentwig, W., Vilà, M., Genovesi, P., Gherardi, F., Desprez-Loustau, M.L., Roques, A., Pyšek, P., 2011. Socioeconomic legacy yields an invasion debt. Proceedings of the National Academy of Sciences of the United States of America, 108, 203-207.

https://doi.org/10.1073/pnas.1011728108

Fisher, M.C., Henk, D.A., Briggs, C.J., Brownstein, J.S., Madoff, L.C., McCraw, S.L., Gurr, S.J., 2012. Emerging fungal threats to animal, plant, and ecosystem health. Nature, 484, 186-194.

https://doi.org/10.1038/nature10947

Fischer N.M., Dool S.E., Puechmaille S.J., 2020. Seasonal patterns of Pseudogymnoascus destructans germination indicate host-pathogen coevolution. Biology Letters, 16, 20200177.

https://doi.org/10.1098/rsbl.2020.0177

Frick, W.F., Puechmaille, S.J., Hoyt, J.R., Nickel, B.A., Langwig, K.E., Foster, J.T., Barlow, K.E., Bartonička, T., Feller, D., Haarsma, A.J., Herzog, C., Horáček, I., van der Kooij, J., Mulkens, B., Petrov, B., Reynolds, R., Rodrigues, L., Stihler, C.W., Turner, G.G. et al., 2015. Disease alters macroecological patterns of North American bats. Global Ecology and Biogeography, 24, 741-749. https://doi.org/10.1111/geb.12290

Fritze, M., Puechmaille, S.J., 2018. Identifying unusual mortality events in bats: a baseline for bat hibernation monitoring and White-nose syndrome research. Mammal Review, 48, 224-228.

https://doi.org/10.1111/mam.12122

FSE European Working Group on WNS (2010). Whitenose syndrome (WNS) in Europe? Fact sheet for cavers, 2 p.

Hoyt, J.R., Langwig, K.E., Sun, K., Parise, K.L., Li, A., Wang, Y., Huang, X., Worledge, L., Miller, H., White, J.P., Kaarakka, H.M., Redell, J.A., Görföl, T., Boldogh, S.A., Fukui, D., Sakuyama, M., Yachimori, S., Sato, A., Dalannast, M., Jargalsaikhan, A., Batbayar, N., Yovel, Y., Amichai, E., Natradze, I., Frick, W.F., Foster, J.T., Feng, J., Kilpatrick, A.M., 2020. Environmental reservoir dynamics predict global infection patterns and population impacts for the fungal disease Whitenose syndrome. Proceedings of the National Academy of Sciences of the United States of America, 117, 72557262. https://doi.org/10.1073/pnas.1914794117 
Hulme, P.E., 2009. Trade, transport and trouble: Managing invasive species pathways in an era of globalization. Journal of Applied Ecology, 46, 10-18. https://doi.org/10.1111/j.1365-2664.2008.01600.x

Kovacova, V., Zukal, J., Bandouchova, H., Botvinkin, A.D., Harazim, M., Martínková, N., Orlov, O.L., Piacek, V., Shumkina, A.P., Tiunov, M.P., Pikula, J., 2018. White-nose syndrome detected in bats over an extensive area of Russia. BMC Veterinary Research, 14, 1-9. https://doi.org/10.1186/s12917-018-1521-1

Leopardi, S., Blake, D., Puechmaille, S.J., 2015. Whitenose syndrome fungus introduced from Europe to North America. Current Biology, 25, 217-219. https://doi.org/10.1016/j.cub.2015.01.047

Lithner, D., Nordensvan, I., Dave, G., 2012. Comparative acute toxicity of leachates from plastic products made of polypropylene, polyethylene, PVC, acrylonitrilebutadiene-styrene, and epoxy to Daphnia magna. Environmental Science and Pollution Research, 19, 17631772. https://doi.org/10.1007/s11356-011-0663-5

Lockwood, J.L., Cassey, P., Blackburn, T., 2005. The role of propagule pressure in explaining species invasions. Trends in Ecology and Evolution, 20, 223-228. https://doi.org/10.1016/j.tree.2005.02.004

Lorch, J.M., Meteyer, C.U., Behr, M.J., Boyles, J.G., Cryan, P.M., Hicks, A.C., Ballmann, A.E., Coleman, J.T.H., Redell, D.N., Reeder, D.M., Blehert, D.S., 2011. Experimental infection of bats with Geomyces destructans causes White-nose syndrome. Nature, 480, 376-378. https://doi.org/10.1038/nature10590

Lorch, J.M., Palmer, J.M., Lindner, D.L., Ballmann, A.E., George, K.G., Griffin, K., Knowles, S., Huckabee, J.R., Haman, K.H., Anderson, C.D., Becker, P.A., Buchanan, J.B., Foster, J.T., Blehert, D.S., 2016. First detection of bat White-nose syndrome in Western North America. mSphere, 1, e00148-16. https://doi.org/10.1128/mSphere.00148-16

Lorch, J.M., Minnis, A.M., Meteyer, C.U., Redell, J.A., White, J.P., Kaarakka, H.M., Muller, L.K., Lindner, D.L., Verant, M.L., Shearn-bochsler, V., Blehert, D.S., 2015. The fungus Trichophyton redellii sp . nov . causes skin infections that resemble White-nose syndrome of hibernating bats. Journal of Wildlife Diseases, 51, 3647. https://doi.org/10.7589/2014-05-134

Petit, E.J., Puechmaille, S.J., 2015. Will reduced host connectivity curb the spread of a devastating epidemic? Molecular Ecology, 24, 5491-5494. https://doi.org/10.1111/mec.13406

Puechmaille, S.J., Frick, W.F., Kunz, T.H., Racey, P.A., Voigt, C.C., Wibbelt, G., Teeling, E.C., 2011a. Whitenose syndrome: Is this emerging disease a threat to European bats? Trends in Ecology and Evolution, 26, 570-576. https://doi.org/10.1016/j.tree.2011.06.013

Puechmaille, S.J., Fuller, H., Teeling, E.C. 2011c. Effect of sample preservation methods on the viability of Geomyces destructans, the fungus associated with White-Nose Syndrome in bats. Acta Chiropterologica, 13, 217-221. https://doi.org/10.3161/150811011X578778

Puechmaille, S.J., Verdeyroux, P., Fuller, H., Ar Gouilh, M., Bekaert, M., Teeling, E.C., 2010. White-nose syndrome fungus (Geomyces destructans) in bat, France. Emerging Infectious Diseases, 16, 290-293. https://doi.org/10.3201/eid1602.091391

Puechmaille, S.J., Wibbelt, G., Korn, V., Fuller, H., Forget, F., Mühldorfer, K., Kurth, A., Bogdanowicz, W., Borel, C., Bosch, T., Cherezy, T., Drebet, M., Görföl, T., Haarsma, A.J., Herhaus, F., Hallart, G., Hammer, M., Jungmann, C., Le Bris, Y. et al., 2011b: Pan-European distribution of White-nose syndrome fungus (Geomyces destructans) not associated with mass mortality. PLoS ONE, 6, e19167.

https://doi.org/10.1371/journal.pone.0019167

Raudabaugh, D.B., Miller, A.N., 2013. Nutritional capability of and substrate suitability for Pseudogymnoascus destructans, the causal agent of bat White-nose syndrome. PLoS ONE, 8, e78300. https://doi.org/10.1371/journal.pone.0078300

Reeder, D.M., Turner, G.R., 2008. Working together to combat White-nose syndrome: A report of a meeting on 9-11 June 2008, in Albany, New York. Bat Research News, 49, 75-78.

Reynolds, H.T., Barton, H.A., 2014. White-nose syndrome: Human activity in the emergence of an extirpating mycosis. In: Atlas, R.M., Maloy, S., (Eds.), One Health: People, Animals, and the Environment, Washington DC, p. 167-181. https://doi.org/10.1128/9781555818432.ch11

Reynolds, H.T., Ingersoll, T., Barton, H.A., 2015. Modeling the environmental growth of Pseudogymnoascus destructans and its impact on the White-nose syndrome epidemic. Journal of Wildlife Diseases, 51, 318-331. https://doi.org/10.7589/2014-06-157

Shelley, V., Kaiser, S., Shelley, E., Williams, T., Kramer, M., Haman, K., Keel, K., Barton, H.A., 2013. Evaluation of strategies for the decontamination of equipment for Geomyces destructans, the causative agent of White-nose syndrome (WNS). Journal of Cave and Karst Studies, 75, 1-10. https://doi.org/10.4311/2011LSC0249

Skarpaas, O., Økland, B., 2009. Timber import and the risk of forest pest introductions. Journal of Applied Ecology, 46, 55-63.

https://doi.org/10.1111/j.1365-2664.2008.01561.x

United States Fish and Wildlife Service. https://www. whitenosesyndrome.org/mmedia-education/unitedstates-national-white-nose-syndrome-decontaminationprotocol-april-2016-2 [accessed April, 2020].

United States Fish and Wildlife Service. https://www. whitenosesyndrome.org/where-is-wns [accessed April, 2020].

Vanderwolf, K.J., Malloch, D., McAlpine, D.F., 2016. Detecting viable Pseudogymnoascus destructans (Ascomycota: Pseudeurotiaceae) from walls of bat hibernacula: effect of culture media. Journal of Cave and Karst Studies, 78, 158-162.

https://doi.org/10.4311/2015MB0138

Vanderwolf, K.J, Malloch, D., McAlpine, D.F., Forbes, G.J., 2013. A world review of fungi, yeast and slime molds in caves. International Journal of Speleology, 42, 77-96. https://doi.org/10.5038/1827-806X.42.1.9

Veilleux, J.P., 2008. Current status of white-nose syndrome in the Northeastern United States. Bat Research News, 49, 15-17.

Verant, M.L., Bohuski, E.A., Richgels, K.L.D., Olival, K.J., Epstein, J.H., Blehert, D.S. 2018. Determinants of Pseudogymnoascus destructans within bat hibernacula: Implications for surveillance and management of white-nose syndrome. Journal of Applied Ecology, 55, 820-829. https://doi.org/10.1111/1365-2664.13070

Warnecke, L., Turner, J.M., Bollinger, T.K., Lorch, J.M., Misra, V., Cryan, P.M., Wibbelt, G., Blehert, D.S., Willis, C.K.R., 2012. Inoculation of bats with European Geomyces destructans supports the novel pathogen hypothesis for the origin of White-nose syndrome. Proceedings of the National Academy of Sciences of the United States of America, 109, 6999-7003. https://doi.org/10.1073/pnas.1200374109

Wickham, H., 2016. ggplot2: Elegant graphics for data analysis. Springer, Cham, $260 \mathrm{p}$.

https://doi.org/10.1007/978-3-319-24277-4 9 
Wildlife Health Australia. https://www.wildlifehealth australia.com.au [accessed April 2019].

Wyatt, T.T., Wösten, H.A.B., Dijksterhuis, J., 2013. Fungal spores for dispersion in space and time. Advances in Applied Microbiology, 85, 43-91. https://doi.org/10.1016/B978-0-12-407672-3.00002-2

Zhang, T., Victor, T.R., Rajkumar, S.S., Li, X., Okoniewski, J.C., Hicks, A.C., Davis, A.D., Broussard, K., La Deau, S.L., Chaturvedi, S., Chaturvedi, V., 2014. Mycobiome of the bat White-nose syndrome affected caves and mines reveals diversity of fungi and local adaptation by the fungal pathogen Pseudogymnoascus (Geomyces) destructans. PLoS ONE, 9, e116149. https://doi.org/10.1371/journal.pone.0116149
Zhelyazkova, V, Toshkova, N., Dool, S., Bonaccorso, F.J., Pinzari, C., Montoya-Aiona, K., Puechmaille, S.J., 2019. Screening and biosecurity for White-nose fungus Pseudogymnoascus destructans (Ascomycota: Pseudeurotiaceae) in Hawai'i. Pacific Science, 73, 357365. https://doi.org/10.2984/73.3.4

Zukal, J., Bandouchova, H., Brichta, J., Cmokova, A., Jaron, K.S., Kolarik, M., Kovacova, V., Kubátová, A., Nováková, A., Orlov, O., Pikula, J., Presetnik, P., Šuba, J., Zahradníková Jr., A., Martínková, N., 2016. Whitenose syndrome without borders: Pseudogymnoascus destructans infection tolerated in Europe and Palearctic Asia but not in North America. Scientific Reports, 6, 19829. https://doi.org/10.1038/srep19829 